\title{
Fra Truman til Trump, fra koldkrig til handelskrig
}

Af Jens Ladefoged Mortensen

Under Truman investerede USA med Marshallhjælpen velvilligt i europæisk økonomi. Den kolde krigs bipolaritet betød, at økonomisk vækst i Europa var i USA's nationale interesse. Under Trump er Truman nærmest vendt på hovedet.

Økonomisk vækst i Europa er blevet til en trussel mod den amerikanske nationale sikkerhed.

Efterkrigstidens liberale handelsorden var ikke altid harmonisk og fredfyldt. Handelstvister er helt normale i en tæt integreret verdensøkonomi. En global handelskrig er derimod unormal, et sikkert tegn på systemsammenbrud. Det er ikke blot amerikansk told på europæisk stål eller EU's gengældelsestold på amerikansk Bourbon, som er problemet. Der er sammenkædningen af handels- og udenrigspolitiske konfrontationer, der tegner et billede af amerikansk retræte fra den liberale orden, fra
Verdenshandelsorganisationen WTO til NAFTA-aftalen, annulleringen af Stillehavsaftalen TPP, tilbagetrækning fra Paris-klimaaftalen, FN-aftalen om Iran, FN-menneskerettighedsrådet og senest Den Internationale Krigsforbryderdomstol ICC.

\section{Mod transatlantismens endeligt?} Flere og flere ser et opbrud i 'transatlantismen', det fælles værdisæt om frihandel, demokrati og retsprincipper, som har understøttet det liberale projekt siden 1945 (Sauerbrey, Anna: 'Is the Trans-Atlantic Relationship Dead'?, Opinion, New York Times, 03.01.18; Schwartz, Madeleine: 'The end of Atlanticism: has Trump killed the ideology that won the cold war?' The Guardian, 04.09.18.). Europa-Kommissionens formand Jean-Claude Juncker talte i sin State of The Union-tale i september 2018 om nødvendigheden af et åbent - men ikke naivt - Europa. 
TTIP faldt sammen, allerede før Trump blev valgt. Amerikanerne ville ikke give sig en millimeter på de mest ømtålelige punkter som fx accept af forsigtighedsprincippet eller åben licitation på offentlige udbud i USA.

Et opbrud i transatlantismen, forstået som en fælles vision og et fælles værdisæt, vil få globale implikationer, fordi værdier, institutioner og magtinteresser grundlæggende hænger sammen i enhver international orden (Sørensen, Georg: 'Magt og Verdensorden', Økonomi og Politik, nummer 1, februar, 2018, s. 7-15). For blot et par år siden delte Washington og Bruxelles en vision om et transatlantisk marked, den Transatlantiske Handelsog Investeringsaftale (TTIP), der som et modtræk til fremvoksende handelsmagter skulle udstikke reglerne for fremtidens verdensøkonomi.

Geoøkonomisk frygtede EU og USA, at tiden var ved at løbe fra en liberal verdensøkonomi. Kun sammen kunne de sikre konkurrencevilkår, der afspejlede de transatlantiske fællesværdier og konkurrencefordele, demokrati, forbrugerbeskyttelse, retsbeskyttelse, og miljøbeskyttelse.

TTIP faldt sammen, allerede før Trump blev valgt. Amerikanerne ville ikke give sig en millimeter på de mest $ø$ mtålelige punkter som fx accept af forsigtighedsprincippet eller åben licitation på offentlige udbud i USA. I Europa var det mange, der slet ikke så TTIP-projektet som reguleret handel, men derimod brutal neoliberalisering, der favoriserede erhvervslivet på demokratiets, miljøets og velfærdsstatens bekostning.
Det virker som en fjern fortid, men det er faktisk kun to år siden. Nu synes håbet om regelstyret globalisering at være afløst af frygten for ukontrollabel handelskrig. Er transatlantismen ved at blive afløst af magtrivalisering?

Truslen om en altomfattende handelskrig er mere end en sort sky $\mathrm{i}$ horisonten. G7-mødet i juni cementerede, hvor galt det står til på tværs af Atlanten. EU og USA synes på vej mod en global handelskrig.

Alligevel lyder der forsonende toner fra de amerikanske og europæiske chefforhandlere i skrivende stund. Hvor handelskrigen mellem USA og Kina er eksploderet, og ingen kan krybe i skjul for den, så forhandles der trods alt stadigvæk mellem Washington og Bruxelles. Da Juncker og Trump mødtes i slutningen af juni 2018 blev der talt om genåbning af noget, der kunne minde om en TTIPultralight aftale, men blot dage senere blev forsoningen afløst af forvirring.

\section{Hvad er en handelskrig?}

Det store spørgsmål er, om Europa vil blive omfattet af den eskalerende handelskrig over Stillehavet. Investorerne er ved at blive nervøse. De er i gang med at revurdere deres globale investerings- og produktionsstrategier, fordi der er sat spørgsmålstegn ved fremtidens spilleregler for verdenshandlen.

Analysen herunder ser nærmere på muligheder for et transatlantisk kompromis. EU er for store til at blive banket på plads ved forhandlingsbordet af 
Trump. Der er potentiale for et kompromis, men også alvorlige hindringer. En af de helt store knaster er USA's indgroede mistro over for WTO-institutionen, for den kolliderer med EU's stærke selvforståelse som en multilateral handelsmagt.

Trump har sagt, at USA vil melde sig ud af WTO, hvis den ikke snart 'opfører sig ordentlig'. Han erklærede samtidigt, at EU er 'næsten lige så slem som Kina' (Mayeda, Andrew: 'U.S.-EU Trade Talks Progress With Trump Eyeing Congress Approval 10.09.18.). Det er så langt fra den transatlantiske samhørighed, som herskede under den kolde krig og i 1990'ernes liberale årti.

En handelskrig er en ukontrolleret kædereaktion af gengældelser af toldsatser mellem handelspartnere. Verdensøkonomien har været forskånet for en åben handelskrig i hele efterkrigstiden.

Der har været handelspolitiske kriser og spændinger, men ingen altomfattende handelskrige. 1930'ernes handelskrig er det mest kendte eksempel. I kølvandet på Wall Street-krakket i 1929 vedtog den amerikanske Kongres den berygtede Smooth-Harvey lovgivning i 1932, som pålagde ekstratold på al amerikansk import. Den blev mødt med massiv gengældelsestold.

Handelskrigen spredte sig hurtigt til verdensøkonomien. Verdenshandlen frøs til, og det skabte en global økonomisk krise. Det fik politiske konsekvenser - fra Folkeforbundets kollaps til Hitlers magtovertagelse. Det var den historiske lære, som arkitekterne

USA brugte handelspolitikken som et incitament snarere end en trussel og tillod europæerne at køre på frihjul, fordi det gav erhedspolitisk mening under den kolde krig.

bag den liberale amerikanske verdensorden tog med sig fra 1930'ernes handelskrig.

\section{Efterkrigstidens handelsorden}

2018 kan blive året, hvor det rå magtdiplomati afløser det regelstyrede handelsdiplomati. Det paradoksale ved situationen er, at USA er ved at nedbryde den handelsorden, det selv har opbygget gennem hele efterkrigstiden. Transatlantismen blev fundamentet for den globaliserende verdensøkonomi. Sikkerhedspolitik smeltede sammen med handelspolitik, et bolværk mod Vestens fjender under den kolde krig.

En udbredt tolkning er, at USA under den kolde krig var villig til at lade de europæiske allierede få del i den $ø$ konomiske vækst, fordi det var i den amerikanske nationale interesse. USA tilvejebragte - og betalte for - en åben verdensøkonomi (Gilpin, Robert: Global Political Economy - Understanding the International Economic Order, Princeton University Press 2001; Frieden, Jeffry A.: Global Capitalism- Its Fall and Rise in the Twentieth Century, W.W. Norton, New York 2006).

USA brugte handelspolitikken som et incitament snarere end en trussel og tillod europæerne at køre på frihjul, fordi det gav sikkerhedspolitisk mening under den kolde krig. Marshallhjælpen var vækstgeneratoren, Verdensbanken og IMF understøttede 


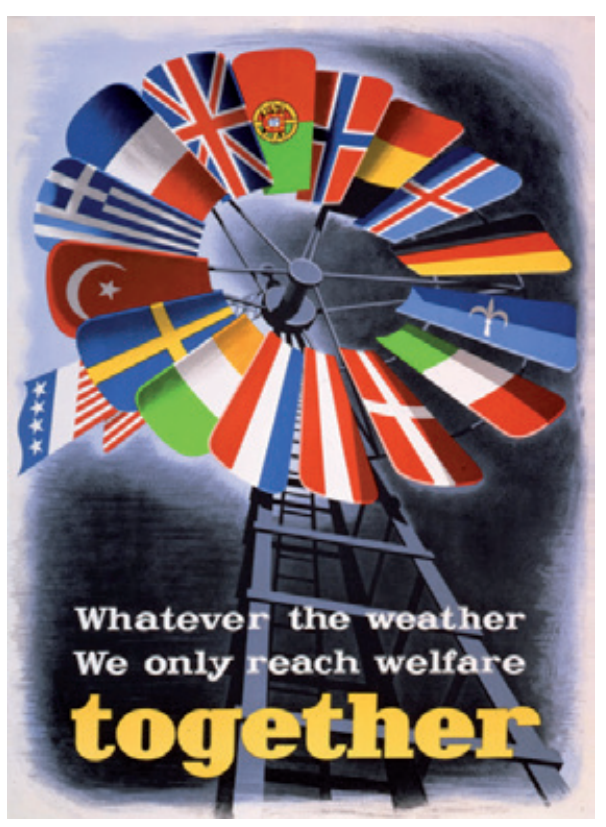

ILL. : E. Spreckmeester [also credited as 'I. Spreekmeester'] published Economic Cooperation Administration via Wikimedia Commons

Plakat for Marshallplanen

verdensøkonomiens stabilitet, GATT muliggjorde eksport til USA's enorme hjemmemarked, og europæisk integration cementerede den liberale orden i Europa. USA agerede som 'godartet' hegemon, der velvilligt tillod deres europæiske konkurrenter at vokse sig store på amerikansk bekostning, fordi det gav udenrigspolitisk gevinst for USA.

Efter den kolde krig var transatlantismen understøttet af stærke transnationale eksportinteresser. Markedskræfterne overtrumfede udenrigspolitikken. Den økonomisk liberale strategi blev nu styrende for amerikansk udenrigs- politik. Og det var en fejl, lyder det nu fra Donald Trump. Hvad der sker nu, er en normalisering af amerikansk udenrigs- og handelspolitik. Trump kan ses som en tilbagevenden til fx 1920 'ernes isolationistiske USA.

Der er andre fortolkninger af efterkrigstidens transatlantiske orden. En mere kritisk tolkning vil påpege, at USA nød godt af den liberale økonomiske orden, den amerikanske forbruger og det amerikanske erhvervsliv fik uforholdsmæssigt meget ud af en åben verdens $\varnothing$ konomi. Det var aldrig en omkostning for USA, snarere omvendt. USA fik vækst på andres bekostning. Amerikanske multinationale firmaer forblev økonomisk og teknologisk overlegne. Amerikanerne havde finansiel overmagt i form af dollaren som international valuta. USA var ikke i forfald, tværtimod; det ekspanderede sin magt over verdensøkonomien (Strange, Susan: 'The Persistent myth of lost hegemony', International Organization, 1987, 41(4) s. 551-574).

En anden tolkning ser ikke den liberale verdensorden som et rendyrket amerikansk projekt, men som et transatlantisk kompromis mellem international frihandel og national velfærdspolitik. Amerikanerne og briterne skabte sammen en $ø$ konomisk orden, der blandede Smith sammen med Keynes.

Handelsliberalisering beroede på en balance mellem frihandelsprincipper og national suverænitet kaldet kompromiset om indlejret liberalisme (Ruggie, John G.: 'International regimes, transactions, and change: embedded liberalism in the postwar economic 
Uanset om transatlantismen byggede på amerikansk sikkerhedspolitik under den kolde krig eller afspejlede et transatlantisk kompromis om indlejret liberalisme, så skabte den transatlantiske orden grobund for en globaliseret verdensøkonomi, der aldrig blev ramt af en ægte handelskrig.

order', International Organization 1982, 36 (2) s. 195-231).

Den regulerede liberalisme havde undtagelsesbestemmelser indbygget for særligt følsomme situationer, hvor staterne legitimt kunne beskytte sig selv. Det sikrede politisk opbakning omkring frihandelsprojektet. Den mest brugte undtagelse er anti-dumpingtold i GATT artikel 6. Hvis fx uforudset import skyller ind over et land, er det efter tilbundsgående undersøgelser tilladt for en tid at iværksætte tidsbegrænsede modforanstaltninger, der skærmer en sårbar industri for konkurrence,. Sådanne modforanstaltninger skal kunne testes retsligt inden for systemet. Andre stater havde også rettigheder.

Essensen af det transatlantiske kompromis var, at staten havde et råderum for sin økonomiske politik, fra velfærdsstat til landbrugs- og industripolitikken. Men kompromiset har i længere tid haft problemer; USA's antidumping-lovgivning har således længe skabt problemer i handelssystemet.

Som en del af kompromiset har der hersket en forståelse for, at dele af udenrigs- og sikkerhedspolitikken fortsat er statens suveræne politikdomæne. En del af handelskrigen handler om en anden undtagelsesbestemmelse, GATT artikel 21, som giver staterne en noget udefinerbar ret til at beskytte sig selv mod enhver import, der truer 'national sikkerhed'. Ordlyden er så bred og upræcis, at GATT artikel 21 har været anset som decideret farlig og aldrig anvendt.

De normale frihandelsregler gælder ikke for $\mathrm{fx}$ militærindustrien eller våbenhandel eller i udenrigspolitiske krisesituationer. Sanktioner bør være godkendt i sikkerhedsrådet, men selv her har staterne valgt at ikke udfordre systemet. Der er en uskrevet norm om ikke at anvende GATT artikel 21. Det er udenrigs- og sikkerhedspolitik, ikke handelspolitik. Ikke desto mindre har USA brugt 'national sikkerhed' til at retfærdiggøre stål- og aluminiumstolden.

\section{Handelskonfrontationer siden 1960} Uanset om transatlantismen byggede på amerikansk sikkerhedspolitik under den kolde krig eller afspejlede et transatlantisk kompromis om indlejret liberalisme, så skabte den transatlantiske orden grobund for en globaliseret verdensøkonomi, der aldrig blev ramt af en ægte handelskrig.

Det har ikke været, fordi der herskede fred og fordragelighed på tværs af Atlanten. Europa og USA har i mange henseender været bitre konkurrenter i mange årtier. Der har været optræk til handelskrig mellem USA og EU flere gange, men aldrig decideret handelskrig. Der har været 
tre bølger af handelskonfrontationer, i 1960'erne, 1970-80'erne og fra midten af 1990'erne til begyndelsen af 00'erne.

I begyndelsen af 1960'erne blev det daværende GATT-system paralyseret af en serie af transatlantiske konflikter om landbrugseksporten. Det var europæiske importkvoter for bl.a. citrusfrugter og kyllinger, som skabte voldsom irritation blandt amerikanske landbrugsinteresser. EF's landbrugspolitik var ifølge USA i modstrid med GATT-forpligtelserne.

Det var ironisk, fordi det var ame-

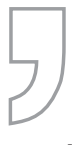

Det er en af historiens ironier, at USA skubbede på for et stærkere WTO-retssystem, men endte med at være en modstander af en stærkere WTO-domstol.

rikanerne, der i midten af 1950'erne fik netop landbrugshandlen undtaget fra GATT-forpligtelserne. Hvor GATT-forhandlingerne indtil de såkaldte Kennedy-runder havde succes med at skære i toldsatserne, var GATT i det meste af 1960'erne ignoreret.

I 1970'erne blev GATT-systemet brutalt genoplivet af USA. I kølvandet på fastkurssystemets sammenbrud sendte præsident Nixon den amerikanske handelspolitik i hænderne på handelsjuristerne. Resultat blev en flodbølge af sagsanlæg mod europæerne, der ikke tøvede med at gengælde anklagerne med sagsanlæg mod USA. Spændingerne blev ansatsen til en ny forhandlingsrunde, Tokyo-runden. GATT blev genoplivet og satte dagsordenen bl.a. om ikke-toldbarrierer for det helt store fremstod for det libera- le handelssystem med lanceringen af Uruguay-runden i 1982.

Efter syv års forhandlinger blev WTO etableret i 1993. Den fik nye handelsemner som $\mathrm{fx}$ tjenesteydelser og intellektuelle ejendomsrettigheder med i sin portefølje. Det fik både USA og EU store økonomiske fordele af. Samtidig blev retssystemet gennemgribende reformeret. Bl.a. fik det nye WTO en formel appelinstans.

Det var faktisk slet ikke et amerikansk ønske. USA ønskede et mere effektivt retssystem, der ikke kunne blokeres politisk. Det var canadierne og europæerne, der krævede en overstatslig juridisk 'kvalitetskontrol' med det styrkede handelssystem. Det er en af historiens ironier, at USA skubbede på for et stærkere WTO-retssystem, men endte med at være en modstander af en stærkere WTO-domstol. Overstatslige domstole har altid været et ømtåleligt emne i amerikansk indenrigspolitik.

Der kom hurtigt handelskrigslignende tilstande på tværs af Atlanten efter 1994. En række EU-USA handelstvister om $\mathrm{fx}$ hormonbehandlet $\mathrm{k} ø \mathrm{~d}$ og GMO-fødevaregodkendelser, Cuba-sanktioner eller Airbus-statsstøtte testede WTO-systemets funktionsduelighed. Men ingen af dem blev til handelskrige. Konflikter blev løst i form af enten WTO-afgørelser eller forhandlede aftaler.

Selvom flere handelstvister ikke blev løst, så blev systemet respekteret. Fx er WTO-kendelserne om EU-forbuddet mod hormonbehandlet kød fra 1998 forblevet en torn i øjet på ameri- 
Hillary Clinton talte om TTIP som 'et økonomisk

NATQ'. Det var en geoøkonomisk nødvendighed, at EU og USA gik sammen for at fremtidssikre en liberal verdensøkonomi, mens tid var.

kanske landbrugsinteresser. Der forhandles stadigvæk om en løsning. EU efterlevede afgørelsen ved at acceptere WTO-straftolden. Det samme gælder GMO-sagen fra 2003. Her tabte EU sagen, fordi risikovurderingerne med GMO-fødevarer trak i langdrag, men WTO krævede ikke, at EU skulle ændre ved forsigtighedsprincippet.

Under TTIP-forhandlingerne pressede amerikanerne på for en tidsbegrænsning for EU's GMO-godkendelser. EU afviste forslaget. Det tætteste vi er kommet på en transatlantisk handelskrig før Trump, er den første 'stålkrig' i 2003. Præsident Bush var, med den nuværende handelsminister Wilbur Ross som rådgiver, også dengang villig til at beskytte den amerikanske stålindustri med toldmure. Bush anvendte dog ikke den nationale sikkerhedsundtagelse. Det endte med en våbenhvile 'inden for' systemet.

\section{TTIP: 'det økonomiske NATO'}

Amerikanerne mistede tålmodigheden med WTO efter sammenbruddet ved ministermødet i Cancun i 2003 og skiftede til bilaterale handelsaftaler. Europæerne var skuffede, men fortsatte støtten til de multilaterale spor frem til omkring 2008. Herefter begyndte EU også at udforske mulighederne for bilaterale handelsaftaler.

Finanskrisen kom til at overskygge handelssamarbejdet, men selv ikke finanskrisen, hvor verdenshandlen i
2008 ellers faldt hele 12.5 pct., blev til en handelskrig. Obama fik med en koordineret G7-indsats modvirket en spredning af beskyttelsesforanstaltninger. Protektionismen udeblev som systemisk problem i verdensøkonomien, og handelsmagterne respekterede de grundlæggende spilleregler.

I 2011 blev en ny æra for transatlantismen indledt. En fælles ekspertgruppe kom med en anbefaling om at påbegynde forhandlingerne om en transatlantisk handels- og investeringsaftale. Det skulle have været verdenshistoriens mest omfattende handelsaftale.

Som nævnt var rationalet italesat som geoøkonomisk, specielt fra amerikansk side. Hillary Clinton talte om TTIP som 'et økonomisk NATO'. Det var en geoøkonomisk nødvendighed, at EU og USA gik sammen for at fremtidssikre en liberal verdensøkonomi, mens tid var.

Det var nødvendigt at imødegå de opstigende magter med en ambitiøs transatlantisk handelsaftale. Europæerne italesatte TTIP mere som en nødvendig kriseforanstaltning. Enhver handelskonfrontation mellem EU og USA blev kanaliseret ind i TTIP-forhandlingerne. Der blev ikke rejst nogen alvorlige sager i WTO.

Ifølge Trump har USA ligget i handelskrig med ikke blot kineserne, men også med europæerne, canadierne, japanerne og mexicanerne i mere end tyve år. 
Det viste sig dog hurtigt, at TTIPprojektet var for ambitiøst. Amerikanerne forventede markedsadgang, igen med landbrugseksporten i centrum, for som vicepræsident Joe Biden udtalte, så skal enhver handelsaftale kunne sælges til kyllingefarmeren i Delaware.

USA's fokus var især på TPP-aftalen, og EU frygtede mest af alt, at USA opprioriterede Stillehavet på bekostning af Europa. Som tiden gik, voksede knasterne ved forhandlingsbordet $\mathrm{i}$ takt med den folkelige skepsis.

Modviljen mod TTIP-projektet eksploderede i 2014, specielt i Europa. I USA var vreden rettet mod TPP og NAFTA. Allerede før Trump blev valgt, gav flere EU-forhandlere og EU-politikere udtryk for mismod og frustration over, at USA ikke flyttede sig en millimeter i forhandlingerne.

Valget af Trump i november 2016 dræbte ethvert håb om en TTIP-aftale. Visionen om et transatlantisk 'fællesmarked' viste sig helt ude af trit med den politiske virkelighed.

\section{Trumps handelskrige}

Donald Trump kommer med en anden forståelse af, hvad en handelskrig er. Ifølge Trump har USA ligget i handelskrig med ikke blot kineserne, men også med europæerne, canadierne, japanerne og mexicanerne i mere end tyve år.

Simultant med transatlantiske handelskrige har Trump kastet sig ud i en kinesisk handelskrig af episke dimensioner, der ud over stål- og aluminiumstold anklager Kina for teknologisk tyveri, skjult investeringstvang og ublu favorisering af kinesiske virksomheder.

Den dagsorden deler USA faktisk med EU, men stålkrigen og truslerne om bilimporttold umuliggør et samarbejde om Kina. Handelskrigen har sammen med $f x$ annulleringen af Iran-aftalen, Paris-aftalen, udmeldelse af FN's menneskerettighedsråd og senest Den Internationale Krigsforbryderdomstol (ICC) rystet den transatlantiske alliance.

Europæiske virksomheder kan potentielt blive ramt af amerikanske Iran-sanktioner. Derfor trækker de fleste europæiske firmaer og banker sig ud af Iran. Europæiske ICC-dommere kan potentielt blive nægtet indrejse i USA. Annulleringen af Paris-aftalen har fået flere til at snakke om klimarelaterede handelssanktioner over for fx USA, hvis de fortsat går enegang.

Isoleret set har fx stål- og aluminiumstolden begrænset effekt på verdensøkonomien, op til en halv promille af forventet økonomisk vækst. Ståltolden fordyrer import af stål og aluminium til USA. Modforanstaltningerne er forsat en brøkdel af total samhandel. De indirekte effekter er mere usikre. Produktion og eksport af alle produkter, der bruger stål og aluminium, vil blive dyrere. Igen, det vil paradoksalt nok ramme amerikanerne hårdest. Omkring 200.000 amerikanere er beskæftiget i stålindustrien. Over 6.000.000 amerikanere arbejder med produktion af stål- og aluminiumsprodukter.

Budweiser har forklaret, at der ikke er nok amerikansk aluminium til 
deres øldåser. Boeing kan ikke klare sig uden massiv import af aluminium. Der er heller ikke megen politisk mening i stålkrigen. Med 25 pct. told på amerikansk stålimport og 10 pct. told på aluminium bliver metalproducenter i Europa og Canada ramt direkte. Europa er efter Canada den største ståleksportør til USA. Det har smadret en potentiel handelspolitisk alliance mod Kina, og det sætter spørgsmålstegn ved forsat samarbejde på selv det sikkerhedspolitiske område.

For EU er det alvorligste faremoment amerikanernes signal om at tilsidesætte de grundlæggende principper om verdenshandel. EU ser stålkrigen som en principsag. Den er et angreb på det regelbaserede handelssystem, der i hele efterkrigstiden har understøttet en åben verdensøkonomi baseret på retsprincipper, diplomati og troværdighed. Det er amerikanernes brug af sikkerhedsundtagelsen til at retfærdiggøre importrestrik- tioner over for dets tætteste allierede, der giver panderynker i Bruxelles.

I Geneve har EU sammen med bl.a. Kina, Canada og Japan formelt anmodet WTO om at undersøge stålkrigen og amerikansk antidumping-lovgivning. Kina har taget til genmæle. Et udsnit af handelskrigen set som igangværende WTO-sager i 2018 er gengivet i tabel 1. Sagerne er stærkt politiske og derfor farlige for WTO. Det er fx næsten utænkeligt, at USA får blåstemplet ståltolden inden for WTO-reglerne med henvisning til stålindustriens betydning for national sikkerhed. USA producerer $60 \mathrm{pct}$. af sit stålforbrug selv.

Amerikanerne kan heller ikke retfærdiggøre tolden som antidumping, da WTO-reglerne kræver, at importpresset er 'uforudset'. Trump har gentagne gange sagt, at den amerikanske stålindustri har tabt arbejdsplader de sidste tyve år. En juridisk test af fx na-

TABEL 1: Udvalgte WTO sager, marts-august 2018

\begin{tabular}{|c|c|c|c|}
\hline WTO sag & Anklagede & Anklager & Dato \\
\hline $\begin{array}{l}\text { Tariff Measures on Certain } \\
\text { Goods from China II }\end{array}$ & USA & Kina (DS565) & 23. august 2018 \\
\hline $\begin{array}{l}\text { Additional Duties on Certain } \\
\text { Products from the United States }\end{array}$ & $\begin{array}{l}\text { EU [DS559) [også } \\
\text { Tyrkiet (DS561), } \\
\text { Mexico (DS560) } \\
\text { Kina (DS558) og } \\
\text { Canada (DS557) }\end{array}$ & USA & 16. juli 2018 \\
\hline $\begin{array}{l}\text { Certain measures on the } \\
\text { transfer of technology }\end{array}$ & Kina & EU (DS 549) & 6. juni 2018 \\
\hline $\begin{array}{l}\text { Certain Measures on Steel and } \\
\text { Aluminium Products }\end{array}$ & USA & $\begin{array}{l}\text { Kina (DS544) } \\
\text { Indien (DS547) } \\
\text { EU (DS548) } \\
\text { Canada (DS550) }\end{array}$ & $\begin{array}{l}\text { 5. april } 2018 \\
\text { 18. maj } 2018 \\
\text { 1. juni } 2018 \\
\text { 1. juni } 2018\end{array}$ \\
\hline $\begin{array}{l}\text { Certain Measures Concerning } \\
\text { the Protection of Intellectual } \\
\text { Property Rights }\end{array}$ & Kina & $\begin{array}{l}\text { USA [DS549, } \\
\text { DS542] }\end{array}$ & $\begin{array}{l}\text { 1. juni } 2018 \\
\text { 23. marts } 2018\end{array}$ \\
\hline
\end{tabular}

Kilde: WTO, 2018 
tional sikkerhed-undtagelsen er en regulær bombe under handelssystemet. Det er ydermere vanskeligt at påvise, hvordan fx kinesisk statskapitalisme favoriserer kinesiske firmaer eller tilskynder til teknologityveri.

\section{Mod en TTIP-light aftale?}

Juncker og Trump mødtes i Washington den 25 juni 2018 i kølvandet på G7-sammenbruddet i Canada. Efter mødes synes et kompromis ikke længere utænkeligt. Den nye transatlantiske dagsorden kredsede om tre forhandlingsemner: EU-import af amerikanske sojabønner og flydende naturgas, eliminering af toldsatser og støtteordninger for industrivarer (andre varer end biler) og reform af WTO.

Til trods for at selv Juncker omtalte mødet som 'godt og konstruktivt', stod der flere uklarheder tilbage efter mødet. Truslen om told på europæisk bileksport blev ikke trukket tilbage, men der var enighed om ikke at tage nye toldsatser i brug, mens forhandlingerne er i gang. Det minder om en slags våbenhvile. Det minder lidt om en udvandet TTIP-dagsorden.

Umiddelbart før Trumps indsættelse som præsident i januar 2017 opsummerede TTIP-forhandlerne, hvor tæt de var på målet. Der var fx enighed om eliminering af al transatlantisk told, der skulle åbnes for handel med flydende gas. Landbrugshandlen var fortsat en knast, og uenigheden på flere af de mere ambitiøse TTIP-emner var uoverstigelig, som $\mathrm{fx}$ reguleringssamarbejde og fødevaregodkendelser, geografiske mærkningsregler, investe- ringsdomstol og åbne offentlige licitationer i USA. Efter måneders handelskrigsretorik pegede juni-topmødet pludselig i retning af en slags TTIP ultralight-aftale.

Transatlantisk landbrugshandel været et konstant problem. Trump var hurtigt ude med en sejrsdeklaration: "We just opened up Europe for you farmers. You're not going to be too angry with Trump, I can tell you. ... you have just gotten yourself one big market that really essentially never existed" (Papenfuss, Mary: 'Trump Boasted To Farmers He Opened European Market. Europe: No, He Didn't', Huffington Post, 27.07.18.).

USA's handelsrepræsentant Robert Lighthizer erklærede foran et senatsudvalg at “... we are negotiating about agriculture, period." Europa-Kommissionens talskvinde kom hurtigt ud med et dementi: "On agriculture, I think we've been very clear on that that agriculture is out of the scope of these discussions" (ibid.).

Der er forskellig opfattelse af, hvad EU og USA egentlig forhandler om. Juncker havde angiveligt foreslået, at $\mathrm{EU}$ ville droppe al told på biler, hvis amerikanerne gjorde det samme. Et krav om gensidig toldsænkning synes ikke urimeligt, vil de fleste mene. Trump afviste dog forslaget øjeblikkeligt.

Mens Junckers og Trumps politiske retorik til tider er ved at overskygge forhandlingerne, synes EU's handelskommissær Malmström og Leithheizer at kommunikere sammen på en mere professionel handelsdiplomatisk måde, uden at Leightheizer på nogen 
måde kan siges at være en blød og eftergivende diplomat. Der kan spores en vis forsigtig optimisme på det seneste. Den transatlantiske handelskrig kan stadig nedtrappes.

\section{USA's dalende troværdighed}

Et af de største problemer er USA's dalende forhandlingstroværdighed. Også Bruxelles har efterhånden mistet tilliden til Trump. Det koster diplomatisk troværdighed at annullere indgåede aftaler. Det andet problem er USA's hårde spil i WTO, hvor amerikanerne har nægtet at udnævne nye dommere til WTO-domstolens appelinstans. Her synes USA og EU at være på direkte kollisionskurs.

Det var ironisk nok Obama-administrationen, som påbegyndte blokeringerne af nye WTO-dommerudnævnelser i 2016. Konteksten var en anden. Situationen er nu kritisk. WTO vil ophøre som funktionel retsinstans senest til december næste år.

USA anklager WTO-dommerne for at gå langt ud over deres juridiske mandat til at behandle retslige aspekter af enkeltstående sager på det eksisterende aftalegrundlag, der er forhandlet på plads af WTO-medlemmerne. Domstolens fortolkninger har været for ekspansive, lyder anklagen. Det har forskubbet balancen mellem forpligtelser og rettigheder.

Det er specielt det europæiske medlem, Peter Van den Bossche, der af amerikanerne blev set som et problem. USA mener, at appelinstansen har skabt nye forpligtelser i efterprøvelse af WTO-afgørelser uden hensyn til, at der har været manglende
Situationen i 2018 minder lidt om 1980'ernes handelskriser. USA truede også dengang med handelsvåbnet over for teknologityveri og piratkopiering, men her blev det hårde diplomatiske pres en 'konstruktiv' krise.

indrømmelser på andre områder for modparten. USA er ikke alene med kritikken. Flere andre WTO-medlemmer kritisere også appelinstansen for at være overdreven legalistisk og aktivistisk.

WTO-krisen er nu akut. Hvis der fortsat blokeres for udnævnelser, kan WTO-appelinstansen ikke være funktionsdygtig den 10. december 2019. Og dermed kan fx stålsagerne eller teknologisagen ikke afsluttes, fordi de ikke kan appelleres.

En løsning kunne være amerikansk-støttede nyudnævnelser. Ved sidste møde i WTO’s tvistbilæggelsesorgan i august 2018 blokerede USA fortsat for dommerudnævnelser. Trump vil melde USA ud af WTO: "If they don't shape up, I would withdraw from the WTO," og "... [the WTO] was the single worst trade deal ever made." (www.bloomberg.com/news/ articles/2018-08-30). Men Trump kan ikke selv trække USA ud af WTO. Det kræver Kongressens godkendelse.

Man kan mistænke Trump for at omgå den amerikanske forfatning ved at dræbe WTO 'indefra' med fortsat blokering af dommerudnævnelser. Det behøver han ikke Kongressens godkendelse til.

Der var ikke mange amerikanske politikere, der ville gå til midtvejsvalg 
i november 2018 på at redde WTO fra et sammenbrud.

\section{Europas svære position}

Efterkrigstiden startede med et atlantisk projekt om genrejsning af Europa. Den kolde krig bragte USA og Vesteuropa tættere sammen, og. europæerne har været USA's tætteste allierede trods handelsskænderierne. Der har altid været stor troværdighed om USA som forhandlingspartner, om end USA altid har spillet hårdt. Det er der nu sat spørgsmålstegn ved. Det øger risikoen for, at det hårde amerikanske forhandlingsspil på tværs af Atlanten bliver til en brutal handelskrig. Situationen i 2018 minder lidt om 1980'ernes handelskriser. USA truede også dengang med handelsvåbnet over for teknologityveri og piratkopiering, men her blev det hårde diplomatiske pres en 'konstruktiv' krise.

Handelsdiplomatiet hang sammen med en klar dagsorden om, at handelssystemet skulle styrkes. En diplomatisk pakkeløsning, Uruguay-aftalen, kom i 1993. Den skabte WTO med dets styrkede retssystem. WTO indeholdt - ironisk nok - den selvsamme appelinstans, hvis dommerudnævnelser amerikanerne nu blokerer for.

Altantismen er et andet ord for det fælles værdigrundlag, der har understøttet efterkrigstidens handels- og udenrigspolitiske samarbejde, men som nu er ved at krakelere. Dermed indvarsles der et opbrud i den liberale verdensorden.

Der er dog stadig tid til en genoplivning af atlantismen.
WTO's nære fremtid er lakmusprøven for, om USA har tænkt sig at trække sig helt tilbage fra den liberale verdensorden.

Juncker-Trump-erklæringen kan ses som et gryende forsoningssignal. Men det er vitterligt et skrøbeligt signal. Der hersker fortsat forvirring om, hvad der egentlig skal forhandles om. Der er fortsat et stærkt interessefællesskab på tværs af Atlanten. Det er basalt set umuligt at adskille sikkerhedspoliske og handelspolitiske interesser.

Et er, at der er et troværdighedsproblem omkring Trumps udenrigsog handelspolitik. Men Trump som person er ikke det eneste, der skaber problemer på tværs af Atlanten. Det er den voksende kløft mellem to kontrasterende værdisæt, der i dag bekymrer transatlanterne.

WTO's nære fremtid er lakmusprøven for, om USA har tænkt sig at trække sig helt tilbage fra den liberale verdensorden. USA har valgt handelskrigen med Kina. Det sætter EU i en sårbar, men også potentiel indflydelsesrig position. Kan EU genskabe et globalt kompromis om reguleret frihandel, eller vil EU bliver trukket ind i den gigantiske handelskrig, som nu er i gang på tværs af Stillehavet.

I værste fald kan EU blive presset til at vælge side. Det rejser også spørgsmålet om, hvorvidt EU hænger godt nok sammen til at tage lederskab i en handelskrig. Kan EU stå alene mellem Kina og USA? 